They have also added the anatomy of the parts and two extra colvured plates, so that the work is now well illustrated with 180 engravings and eight plates in colour. The section upon the eye and its affections, from the pen of Dr. Wippern, does not concern us here. In England ouhthalmology and otology are considered to be specialties of sufficiently large scope to be kept apart. Dr. Ballenger is responsible for the remainder of the book, and has done his work well. For a small text-book the work is an excellent one, and the stanilard is well maintained throughout. Descriptions are clear, and wherever a good diagram or illustration can be of assistance in explanation of the text there is always one to be found. We would, however, counsel a more rigorous proof-reading in future editions. A useful portion of the work is the part relating to life insurance. This the author divides into diseases which should not bar the applicant, those which render him a doubtful risk, and those which render him an unsafe risk. We agree with most of his decisions, but we fail to see why ankylosis of the footplate of the stapes should be included in the third category.

Macleod Yearsley.

War Otitis and War Deafness; Diagnosis, Treatment, Medical Reports By $H$. Bourgeois and M. Sourdille; preface by MédecinInspecteur Toubert. English translation edited by $J$. Dundas Grant, M.D. With 31 illustrations and 6 plates. University of London Press, Ltd. Paris : Masson et Cie, 1918.

This book consists of 230 pages with numerous illustrations and diagrams, and is a translation from the French manual by Bourgeois and Sourdille, edited in English by Dundas Grant. It is one of the Military Medical Annuals, the general editor of which is Sir Alfred Keogh. The amount of information this book contains and its value even to the initiated is really astounding.

It is an extremely difficult thing to state practically and concisely the experience that one has personally gained when dealing with otological cases over a period of years, and still more difficult to render these recorded opinions accurately in another language as Dr. Dundas Grant bas done, and he deserves the highest praise for the way in which he has translated the work. The fact that it does not appear to be a translation from a foreign language gives an added merit to this manual.

The book is well worth reading, and, what is not always the same thing, well worth possessing.

H. J. Banks-Davis.

\title{
NOTES AND QUERIES.
}

A New Symptom of Labyrinth Fistula.

Sir,-In Dr. Mygind's article entitled "A New Symptom of Labyrinth Fistula," which was published in the Jovrwal of Lary ngologr, Rhinology, and OTOLOGY for May last (vol. xxxiii, part 5, p. 146), he describes certain observations produced in patients with labyrinthine disturbances, as influeneed by compression of the carotid artery.

As Dr. Mygind states, "This symptom does not seem to have been described before," I feel sure there are many otologists who will be interested to know that I made similar observations, some of which I described in a paper read before the Otological Section, Royal Society of Medicine, in 1909 and subsequently reported in your journal (see "The Problem of Vertigo-some New Data obtained in a Research into the Functions of the Semicircular Canals in Relation to Movements of the Eyeball in the Human Subject," Proc. Roy. Soc. Med., April, 1909, pp. 65-68).

There I referred to eight cases in which spontaneous nystagmus associated with a defunct labyrinth was arrested by compression of the carotid, and the ninth 
case, one of long-standing defunct labyrinth, in which spontaneous nystagmus did not exist, but which was induced by compression of the carotid on the normal side.

London, $W$.

Yours, etc.,

SYDNEY ScoTT.

The Laryngolory of our Grandfathers.

RichaRD BARHAM ("Ingoldsby") died from cancer of the throat. Judging from the symptoms which he himself described it involved the larynx and pharynx. On May 29; 1845, barely two months before he died, he penned a most pathetic and graphic account of his illness and its treatment. This was sent to his old friend Mr. Hughes, the inspirer of his "Ingoldsby Legends," and published in Bentley's "Miscellany," June, 1862. It is a striking picture of the painful disease recorded by the sufferer, almost complete in its clinical details. In it we read of the vocal signs, of his heroic toleration of the periodic "touches with lunar caustic," and of his quiet protest against "pil. hyd. $\bar{c}$ cret." What must the dear old man have suffered! He dates his trouble in 1844 from " unguardedly swallowing the core of a pear," which got into his "windpipe."

His son tells us that he was attended by Drs. Roberts and Scott, with "the Eminent Surgeon Mr. Coulson."

"The Bulletin" here quoted was written on May 29, 1845. He died on June 17 of that year.

" ' Why I can't produce a note!

I can't sound one word, I think, whole,

But they hobble,

And they gobble,

Just like soap-suds down a sink-hole,

Or I whisper like the breeze

Softly sighing through the trees." "

“Well, Sir - never mind, Sir,

We'll put all to rights you'll find, Sir,

Make no speeches,

Get some leeches;

You'll find twenty

Will be plenty,

Clap them on, and let them lie

On the pomum Adami;

Let them well your trachea drain,

And your larynx,

And your pharynx -

Please put out your tongue again!

" Now the Blister!

Ay, the blister!

" "When it rises,

Snip it, Sir; and then your throat on

Rub a little oil of croton :

Never mind a little pain !

Now, Sir, I must down your maw stick

This small sponge of lunar caustic,

Never mind, Sir,

You'll not find, Sir,

I, the sponge shall leave behind, Sir,

Or my probang make you sick, Sir,

I shall draw it back so quick, Sir;-

This I call my prime Elixir?

Now, Sir! Choking?

Pooh! you're joking-

Bless me! this is quite provoking!

Stay, Sir !-gently !-take it easy!

What can make you, Sir, so wheezy?

There, Sir! that will do to-day,"

Wratt Wingrave.

1 | Life and Letters | of the | Rev. Richard Harris Barham | By His Son | Lon. 1870. 


\title{
Lancet.-"We have nothing but praise for this Annual."
}

\author{
THIRTY-SIXTH YEAR. NOW READY.
}

Fully Illustrated in Colours and Black and White. Price $10 \%$ net.

\section{THE \\ MEDICAL AN ANNUAL,

\section{A YEAR BOOK OF TREATMENT, AND PRACTITIONER'S INDEX :}

\author{
Being a Review of the World's Progress in Medicine and Surgery, \\ arranged in Alphabetical order for Easy Consultation.
}

\section{Contributors :}

E. WYLLYS ANDREWS, A.M., M.D., Chicago. JOSEPH G. HLOMFIELD, B.A., M.D.

FRANCIS D. BOVD, C.M.G., M.D., F.R.C.P. FRANCIS J. CHARTERIS, M.D., B.CH. JOHN D. COMRIE, M.A., M.D., F.R.C.P. LEWIS A. CONNER, PH.B., M.D., New York. CAREY F. COOMBS, M.D., F.R.C.P.

W. H. DOLAMORE, M.R.C.S., L.R.C.P., I.D.S.R.C.S. JOHN S. FRASER, M.B., CH. B., F.R.C. W. E. FOTHERGILL, M.A., M.D. DAVID MCV. FLECK, м.в., Сн.в. HERBERT FRENCH, M.A., M.D., F.R.C.P. EDWARD W. GOODALI, M.D., B.s.

C. THURSTAN HOLLAND, M.R.C.S., L.R.C.P.
J. RAMSAY HUNT, M.D., New York. ROBERT HUTCHISON, M.D., F.R.C.P. FREDERICK LANGMEAD, M.D., F.R.C.P. E. G. GRAHAM LITTLE, M.D., F.R.C.P. CHARLES FRED. MARSHALL, M.D., F.R.C. BEDFORD PIERCE, M.D., F.R.C.P. JOSEPH PRIESTLEY, B.A., M.D., D.P.H. SIR LEONARD RŌGERS, Lt.-Col. T.M.S., M.D., F.R.C.S., F.R.C.P., Calcutta.

A. HUGH THOMPSON, M.A., M.D.

J. W. THOMSON WALKER, F.R.C.S.

W. I. DE COURCY WHEELER, B.A., M.D., F.R.C.S A. GASCOIGNE WILDEY, Dep. Surg.-Gen., R.N. MARGUERITE WILSON, M.B., CH.B., Glasgow.

THIS year's volume aims, like its predecessors, to be a faithful reflex of current Medical and Surgical thought. It is, therefore, of necessity coloured by the consideration of the many new problems which are thrust upon us by the War. These problems will confront the general Practitioner on every hand, and he must be prepared to deal with them.

Hence the current volume has a unique value, in that it furnishes the reader with a careful review of the latest achievements in War Surgery and Medicine, which will be of value now and in the years to come, and which cannot be obtained from any other source.

The civil side of the Practitioner's work has, of course, not been neglected.

The new "Annual" continues to be, as in the past, a digest of the best modern teaching culled by experts from the medical literature of the world.

\section{BRISTOL, ENG. : JOHN WRIGHT \& SONS LTD.}

\section{LONDON : SIMPKIN, MARSHALL, HAMILTON, KENT \& CO. LTD.}




\section{or. Irwin Moore's UNIVERSAL FORCEPS}

For Removing Foreign Bodies from the CEsophagus, Trachea, or Bronchi. nd ENDOSCOPIC CUTTING FORCEPS or SHEARS nd

For Cutting through Tooth-plates, Pins, or Bones.

\section{Dr. William Hill's EXPANDING GSOPHAGOSCOPE}

For assisting in Removal of Impacted Tooth-plates, etc.

See LANCET, May I3th, 1916.
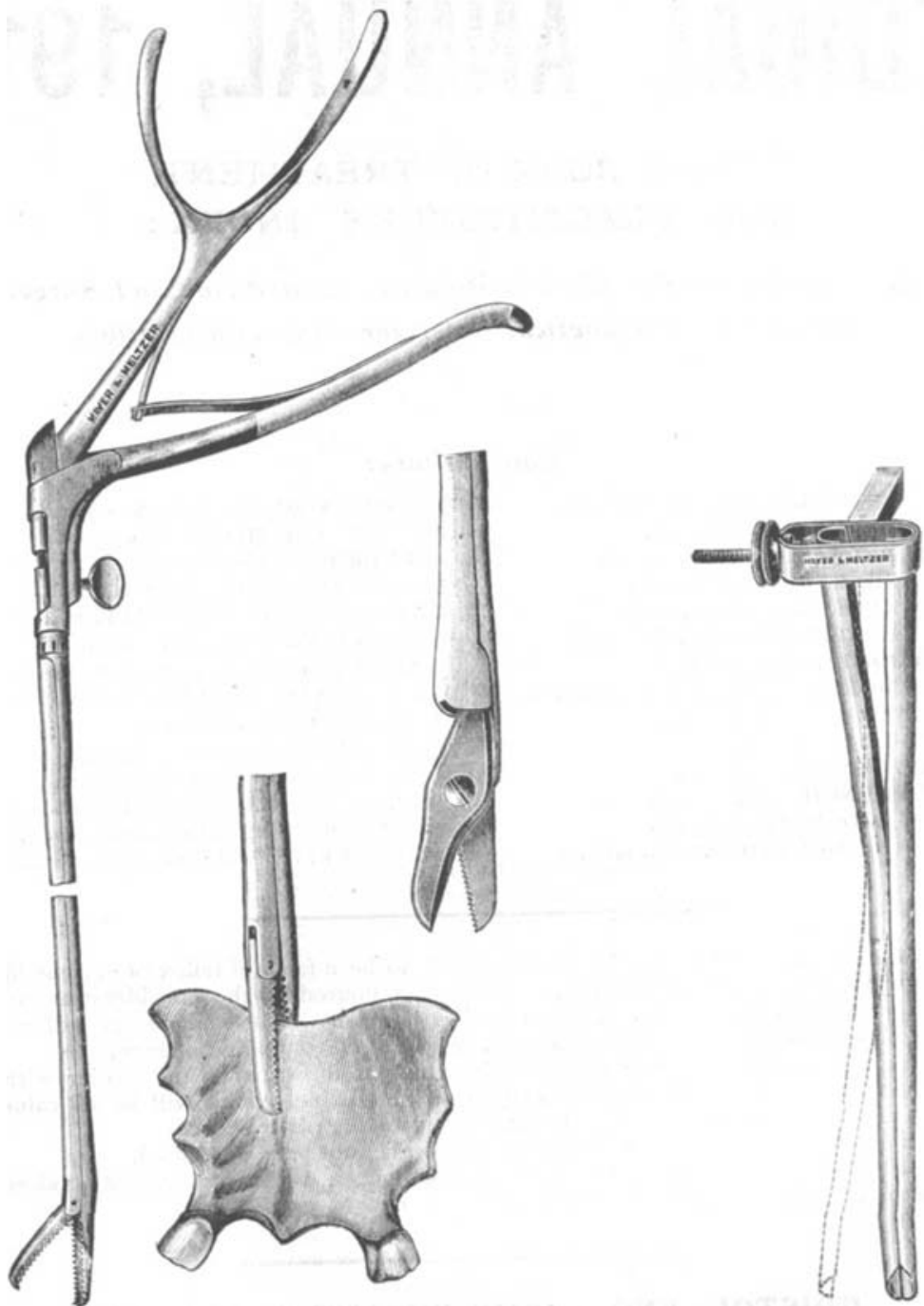

FULL PARTICULARS ON APPLICATION.

MAYER \& MELTZER, 7I, GT. PORTLANd ST., LONdon, W. 


\section{M A Y $\mathrm{Y}$ ER
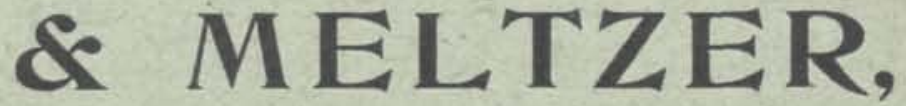

Surgical Instrument Makers. ESTABLISHED OVER FIFTY YEARS.

Regulating Apparatus for the

\section{Administration of Warm Anaesthetic Vapours.}

(Vide article in LANCet, Jan. 8th; 1916, by FrAncis E. ShIPwAY, M.A., M.D.Cantab.)

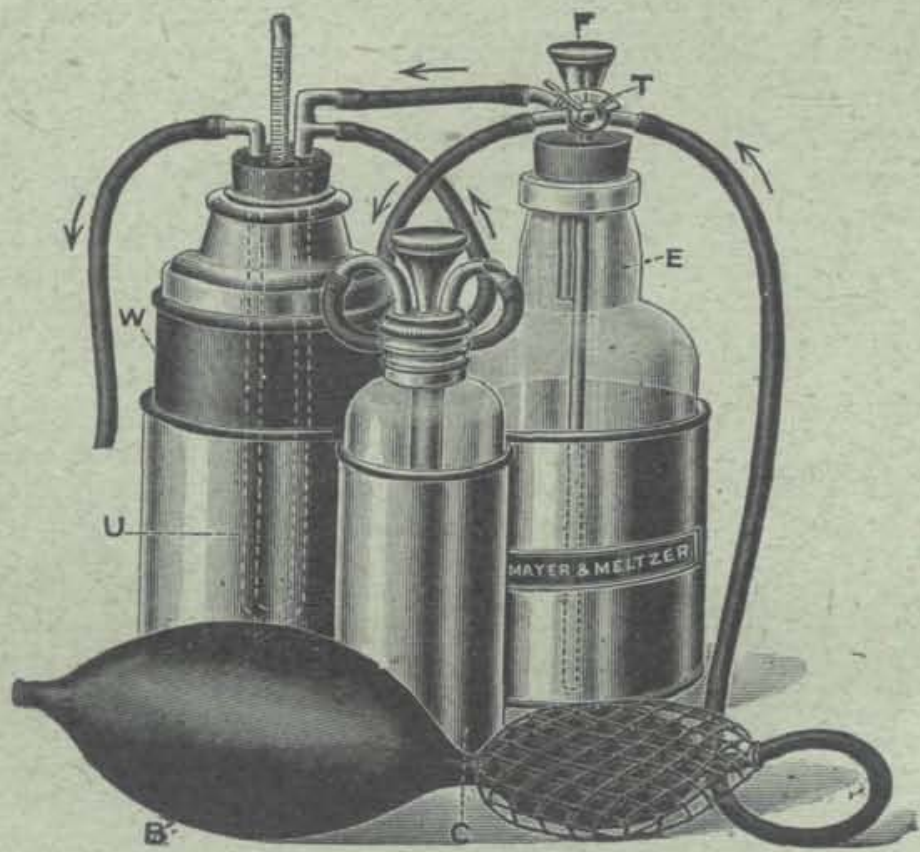

The Administration of Warm Ether Vapour has all the advantages of the Open Ether Method, and is safer. There is less loss of body heat, less shock, less consumption of the anasthetic.

\section{Price \&3 $150 \quad$ H with chloroform Attachment $\& 4176$}

MAYER \& MELTZER, 71, GREAT PORTLAND ST., LONDON. Contractors to the War Office. 


\section{The "Allenburys" \\ (мвдссате) Throat Pastilles}

Efficient

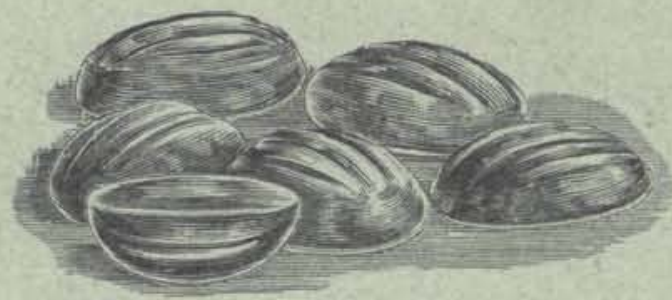

Palatable

The basis of the "Allenburys" Throat Pastilles is a special pâte de jujube. The pastilles are demulcent, soluble and palatable, and contain accurate amounts of pure active drugs. They dissolve slowly and uniformly, so ensuring the thorough suffusion of the mucous membrane, and the prolonged continuous direct effect of the active ingredients.

The following pastilles are largely used, and have been found from long practical experience to be very efficacious.

No. 9. Menthol, Cocaine and Red Gum

Menthol, $\mathrm{gr}$. 1/20th; Cocaine, sr. 1/40th ; Red Gum, sr. 2

No. 23. Eucalyptus and Red Gum

No. 28. Compound Guaiacum

No. 29. Compound Rhatany

No. 38. Chlorate of Potash, Borax and Cocaine

No. 75. Formaldehyde and Menthol

Formaldehyde, min. 1; Menthol, fir, 1/40th

No. 77. Formaldehyde and Cinnamon Oil

Formaldehyde, min. $1 ;$ Ol. Cinnamon. min. $\frac{1}{2}$

A detailed list of the varieties made will be sent on application.

IMPORTANT.-To ensure the supply of these active and reliable medicinal products, medical men should designate the "ALLENBURYS" Pastilles in their prescriptions.

\section{Allen \& Hanburys Ltd. London}

NIAGARA FALLS, N.Y. TORONTO, BUENOS AIRES. DURBAN. SYDNEY, 